\title{
FOREIGNIZATION AND DOMESTICATION STRATEGIES IN INDONESIAN TRANSLATIONS OF TAO TE CHING
}

\author{
Pauw Budianto \\ Wuhan University, Wuhan, Tiongkok \\ email: pauwbudianto@foxmail.com
}

\begin{abstract}
As a cultural dialogue, translation has two main ways: foreignization or domestication. These two translation methods are also reflected in the Indonesian translations of the Tao Te Ching. This article attempts to analyze the performance of these two translation methods in nine books of Indonesian Tao Te Ching translations, including the title of the book and the main philosophical terms (Dao, De, Ziran, Wuwei). This is a qualitative descriptive study, with literature survey as the main method of data collection. The results show that the tensions between the two translation methods in the nine versions of Indonesian translations of the Tao Te Ching are different, reflecting a complex phenomenon.Translation of the title of the book, mostly used combination between foreignization and domestication strategies, kept the book name Tao Te Ching and subtitles that expressed what kind of book was the Tao Te Ching in the translator's mind. Dao's translations had a trend of foreignization, while De's were exactly the opposite. Ziran's translations mostly used thedomestication strategy, and Wuwei's had a trend of foreignization in some newest translations.
\end{abstract}

Keywords: foreignization, domestication, Indonesian translations, Tao Te Ching

\section{STRATEGI FOREIGNISASI DAN DOMESTIKASI DALAM TEKS-TEKS TERJEMAHAN TAO TE CHING BERBAHASA INDONESIA}

\begin{abstract}
Abstrak
Sebagai suatu bentuk dialog antarkultur, penerjemahan terutama memunyai dua cara, yakni foreignisasi dan domestikasi. Fenomena kedua metode penerjemahan ini juga muncul dalam teks-teks terjemahan Tao Te Ching berbahasa Indonesia. Artikel ini menganalisis bagaimana fenomena kedua metode penerjemahan ini terjadi di dalam teks-teks terjemahan tersebut yang terdiri atas sembilan versi berbeda dari berbagai tahun terbitan, terutama terkait penerjemahan judul buku dan penerjemahan konsep-konsep utama dalam Tao Te Ching (Dao, De, Ziran, Wuwei). Penelitian ini merupakan penelitian diskriptif kualitatif dengan studi literatur sebagai metode utama pengumpulan data. Hasil penelitian menunjukkan bahwa tensi antara kedua metode penerjemahan tersebut dalam teks-teks terjemahan Tao Te Ching berbeda satu dengan yang lain menampilkan fenomena yang cukup rumit. Penerjemahan judul buku kebanyakan menggunakan perpaduan foreignisasi dan domestikasi mempertahankan judul asli Tao Te Ching dan judul
\end{abstract}


kecil yang menunjukkan buku seperti apa Tao Te Ching di benak penerjemah. Penerjemahan kata Dao memunyai kecenderungan foreignisasi, penerjemahan kata De sebaliknya lebih cenderung domestikasi. Penerjemahan kata Ziran lebih banyak menggunakan domestikasi, penerjemahan kata Wuwei ada kecenderungan foreignisasi di beberapa karya terjemahan terbaru.

Kata Kunci: foreignisasi, domestikasi, teks Tao Te Ching, Bahasa Indonesia

\section{INTRODUCTION}

The Tao Te Ching is one of the most famous Chinese classics that has been translated into many languages in the world. It was written by Laozi, who lived in the Chu State in ancient central China, in the period of Chunqiu. The written history book about him was very rare, one of the most reliable source was from the book of history or 《史记》Shiji, written by Sima Qian in the Han dynasty. According to this source, Confucius (551479 BC) had ever come to Lao Tzu and learned about rites, then after he came back, he told his students that he had just met a dragon. From this record we could guess that Lao Tzu was elder than Confucius, but lived at the same period. (Fu, 2015:1).

Researchers are accustomed to using the author's name to name Chinese classics, so Lao Tzu's book is also called Lao $T z u$, written in Chinese character with book title mark 《老子》. After the Han Dynasty (about 200 A.D.), people also called it《道德经》/ “Tao Te Ching”, which means the classic about Tao and Te (virtue/morality). In 661, the Tao Te Ching was first translated into Sanskrit; the Latin version was sent to the Royal Society of London as a gift in 1788; in 1823, Professor J.P. Abel Remusat translated some extracts of the Tao Ching, which enabled European intellectuals to begin to understand Taoism; and then in 1842, his student Stanislas Julien published the first complete annotation of the Tao Ching in Europe (Paris). The first Russian translation was published in 1828; the German translation was published in 1870; and the first English translation was made by John Chalmers in 1868. Most translations are in English, German and French (Cui, 2012:12-14).

Translation is a cross-cultural dialogue. Translating Tao Te Ching into Indonesian means bringing the culture behind the book to Indonesian readers. Translators can use at least two different methods: replacing the source culture with the target culture (domestication) or preserving the differences between the source culture and target culture (foreignization). These two methods exist only when there are differences in language expression and cultural connotation (Yang, 2010). Domestication and foreignization are continuous unity, not dualistic opposition. They are related to the translator's ethical choice. Therefore, any translation will be in the tension between domestication and foreignization. Venuti hold that "domestication" and "foreignization" fundamentally demonstrate the ethical attitudes toward foreign language texts and cultures, as well as the 
ethical effects of the choice of translated texts and the use of translation strategies, while words such as "fluency" and "resistance" fundamentally demonstrate the discourse characteristics of translation strategies related to readers' cognitive processes." (Munday 2014, 210).

Most of Tao Te Ching translation research were on English translations. Tao Yuan \& Yu Fengjun (2013) through a quantitative analyzes of 55 English translations, concluded that English translations of Tao Te Ching trend to be foreignized, the trend of foreignization in English translations especially expressed in phonetics, image and structure. Foreignization in phonetics is the word Tao/ Dao to translate the main concept of 道 (Dao) in Tao Te Ching, while foreignization in images are water (to translate水 shui), straw dogs (to translate刍狗chugou), baby (to translate婴儿 ying'er or赤 子chizi), small fish (to translate小鲜xiao xian), etc. (Tao Yuan \& Yu Fengjun, 2013).

Kwee Tek Hoaij in introduction of his book 《Tao Teh King》 (published 1938), stated that when he translated Tao Te Ching to Indonesian (Malay language) in 1935 and published it part by part in Moestika Dharma magazine, there was no Indonesian (Malay language) version found before. From this information, we could know that the Indonesian version of Tao Te Ching began in 1935 (Kwee, 1938), but the first complete Indonesian version was published in 1937 translated by Tan Soe Djwan (Tan, 1937). Up to now, at least nine versions of the Indonesian complete translation of the Tao Te Ching 81 chapters have been published. These books are valuable documents for the study of Indonesian transla- tion of ancient Chinese classics. Translators have made great contributions to the study of Indonesian translation of ancient Chinese classics. These studies are of great significance to the translation of ancient Chinese classics, especially Tao Te Ching into Indonesian in the future (Pauw, 2016).

This paper attempts to discuss the phenomenon of foreignization and domestication in the nine different versions of the Indonesian translation of the Tao Te Ching, including the title of the book and the main philosophical terms (Dao, De, ziran, \& wuwei).

\section{METHODS}

This is a qualitative-descriptive research, with literary study as main data collection method. Data analysis are presented in descriptive verbal presentation according to foreignization dan domestication translation strategies theory used as analysis point of view. Main data sources of this research are nine books of complete Indonesian translations Tao Te Ching from 1937 to 2014. Secondary data are research on Tao Te Ching by many experts in China. This research limited its scope of analysis on foreignization and domestication translation strategies of book titles and four main philosophical terms in the Tao Te Ching (Dao, De, Ziran, Wuwei). Investigations of these philosophical terms in Tao Te Ching firstly conducted to know exactly in which sentences exist in the original version, and to make it easier to find the translations in the nine books of Indonesian translations. Then the investigations of each term translation in these nine books of translations, analyzing it and discuss it one by one separately. Analysis 
and discussions especially used comparative method to make clear the trend of each term translation strategies (foreignization or domestication) among the nine versions existed from 1937-2014.

\section{RESULTS AND DISCUSSIONS \\ Result}

So far, at least nine complete Indonesian translations of the Tao Te Ching have been published (Pauw, 2016), the book titles of these books are below: (1) Too Tik King: Kitab Kebatinan Lao Tse Boeat: Djaman doeloe, sekarang, dan sebeloen dateng (Tan, 1937); (2) Tao Teh King: Kitab peladjaran philosofie Tionghoa jang paling koeno, menerangkan azaz-azaz dari Taoisme, atawa ilmu boeat mendapet katentreman dan kebebasan hidoep (Kwee, 1938); (3) Tao Teh Ching (Liem 1960); (4) Tao-Te-Tjing: Kitab tentang Djalan dan Saktinja (Tjan, 1962); (5) Tao Tee Cing (Kitab Suci Taoisme) (Majelis Tridharma, 1995); (6) Tao The Ching Bagi Orang Modern (Khrisna, 1999);

(7) (Laozi) Daodejing: Kitab Kebijakan dan Kebajikan (Tjan, 2007); (8) Daodejing: Kitab Suci Utama Agama Tao (Lika, 2012), dan (9) Daodejing: The Wisdom of Laozi (Wang, 2014).

Transliteration was commonly used in the translation of the title of the book, but there were different phenomena in its writing. Tan 1937 and Kwee 1938 versions recorded the pronunciation of the Chinese dialect (Minnan) using Indonesian Latin letters. The 1960-1999 versions (Liem 1960; Tjan 1962; Majelis Tridharma 1995; Khrisna 1999) used different pronunciation methods in Indonesian, while the Tjan 2007, Lika 2012 \& Wang 2014 versions used Chinese Pinyin.
On the other hand, the translators interpreted it through the subtitles that follow. From these subtitles, we can see what kind of book the Tao Te Ching is in the translator's mind. The Majelis Tridharma 1995 and Lika 2012 versions emphasized that the Tao Te Ching was a classic of Taoism or Tao religion. The Tan 1937 translation emphasized that the Tao Te Ching was a classic of spiritual navigation. The Kwee 1938 translation of the Tao Te Ching regarded it as a Chinese philosophical work. The Tjan 1962 translation emphasized that Tao Te Ching was Tao and its superpower ability. The translation of this book seems very similar to The Way and Its Power, published in London in 1934 by A. Waley. The Wang 2014 version clearly pointed out that Tao Te Ching was Lao Tzu's wisdom. The Tjan 2007 version also regarded Tao Te Ching as a classic of wisdom and good deeds. The Khrisna 1999 version emphasized the role of the Tao Te Ching for modern people, that is to say, the Tao Te Ching can serve as a realistic guide for modern people's life.

Therefore, the nine Indonesian versions translation methods of Tao $\mathrm{Te}$ Ching book title commonly used combination of foreignization and domestication strategies. Foreignization strategy was used to show to Indonesian readers the book as foreign culture product, while domestication was used to show to Indonesian readers, the main content of Tao Te Ching. This combination strategies are very effective to bring Tao Te Ching to and made it accepted by Indonesian readers. 


\section{Discussion}

The Tao Te Ching is a book about Dao De / Tao Te (morality). Most versions of the Tao Te Ching were composed of "Tao Ching" or "book on Tao" (from Chapter 1 to Chapter 37), and "Te Ching" or "book on Te" (from Chapter 38 to Chapter 81) (Only the silk book Tao Te Ching (bo shu) had different chapters sequence: De Ching in the front and Tao Ching is in the back). It seems that Dao/ Tao and De/Te are the two main ideas Laozi wanted to tell us through the Tao Te Ching. Besides these two main ideas, "ziran" and "wuwei" also become Tao Te Ching main philosophical concepts. We shall focus on the translation strategies of these four main philosophical concepts of Tao Te Ching in the nine versions of Indonesian translation books.

\section{Translation Strategies of “Tao道”}

The word "Tao" appeared 73 times in 81 chapters of Tao Te Ching. They have different meanings in each chapter and sentence (Chen, 1999:2-13). There are at least three meanings of Tao in Tao Te Ching: 1. Mother of all things; 2. Law of nature; 3. The rules of human life. Through the analysis of the word "Tao" in every chapter and sentence of the Tao Te Ching, we found that the meaning of the words "Tao" in the Tao Te Ching are mostly related to the moral norms in human life, the second is "Tao" as the natural law, and the last one is "Tao" as the mother of all things. According to these data, Chen Guying concluded: "Although the metaphysical color of Lao Tzu's philosophy was very strong, in fact, his main concern was people's life and politics." (Chen, 1999:29).
In the nine Indonesian versions, the word "Tao" was sometimes translated into "Too, Tao and Dao" by means of foreignization strategies. Tao is the most common, Dao is more common in recent versions, and Too only appears in earlier versions. In addition, the word "Tao" has been translated into "wet toehan" (God's law), "wet nature" (nature law) and "Djalan" (The Way) by domestication strategies.

The existence of these two translation strategies in Indonesian versions were very complex, showing varying degrees of bipolar tension. Among the nine versions, the most consistent one was the Tjan 1962 version, which translated all the word "Tao ( 道)" in the Tao Te Ching into "Djalan". This translation strategies represented the highest degree of domestication among the nine versions. Even the second word "Tao" in Chapter 1, “道可, 非常道” was also translated as "yang dapat digunakan sebagai djalan" (that can be used as the way), the translator still using the word "djalan" in this translation sentence.

道可道, 非常道（Tao Te Ching chapter 1)

“Djalan”Jang Dapat Digunakan Sebagai Djalan (Tjan, 1962:39).

Almost all experts interpret the second word of "Tao" as "can be said or expressed in language", which has nothing to do with Laozi's philosophical term "Tao" (Liu 2011; Chen 1999; Fu 2012). The Tjan 1962 translation can be used as a different point of view for further discussion.

The highest degree of foreignization strategy appeared in Wang 2014 transla- 
tion. Wang 2014 was very consistent in translating "Dao (道)" into "Dao". The word "Dao" appeared 73 times in this translation, which were exactly the same number as the word "Dao" in the original Tao Te Ching. (Chen 1999:13). But the word "Dao" in his translation was not always as isolated word, sometimes it became a phrase when associated with other word, as existed in these chapters: (chapter 8): prinsip Dao (the principal of Tao; (chapter 14): falsafah Dao (philosophy of Tao; hukum Dao (the law of Tao); (chapter 15): berjiwa Dao (have the spirit of Tao); (chapter 41): Maha Dao (the great Tao); (chapter 53): jalan raya Dao (the high way of Tao). For examples:

故几于道 (Tao Te Ching chapter 8)
mendekati prinsip Dao (Wang,
2014:43)

执古之道...是谓道纪 (Tao Te Ching chapter 14)

Menguasai falsafah Dao jaman kuno dahulu...ini adalah hukum Dao (Wang, 2014:65)

古之善为道者 (Tao Te Ching chapter 15)

Orang yang berjiwa Dao pada jaman dahulu (Wang, 2014:68)

上士闻道 (Tao Te Ching chapter 41) Orang yang memiliki kecerdasan tinggi mendengar Maha Dao (Wang, 2014:161)

大道甚夷 (Tao Te Ching chapter 53)

Jalan raya Dao adalah lebar dan luas (Wang, 2014:200)
Other translations were in tension between two poles of domestication and foreignization. Through the investigation of "Too, Tao and Dao" in the translated text, we can rank the degree of foreignization from high to low: Kwee 1938 (Tao: 67 times), Lika 2012 (Dao: 65 times), Tjan 2007 (Tao: 56 times), Majelis Tridharma 1995 (Tao: 53 times), Liem 1960 (Tao: 51 times), Khrisna 1999 (Tao: 48 times), Tan 1937 (Too: 10 times). These results indicate that besides the Tan 1938 version, there was almost a hierarchical model: the newer version had the higher degree of foreignization in translating the word "Tao (道)".

Through the analysis of the nine versions, we found that the translation strategies of the word "Dao道" in the translated versions embodied a very clear regularity, and the translation versions from the oldest to the newest one basically tend to be foreignized. The earlier the translation, the integration of domestication and foreignization strategies confusion happened, did not clearly reflect the clear positioning of the word "Dao" in the translation. The more modern versions clearly reflect the law of the existence of the word "Dao". Although some additional explanatory attributes are added to the translated words of the word "Dao" according to the meaning of the context, the word "Dao" almost covered all the chapters of the translation, leaving the readers with a profound philosophical category of "Dao". This foreignization strategy also brings about a neat translation effect.

\section{Translation Strategies of “Te德”}

The word “Te德” in Tao Te Ching also expresses rich content. Mr. Zhang Dainian believes that the word “Te德” in Lao Tzu's Tao Te Ching basically contains 
two meanings: one is the general meaning of Te德, that is, the meaning of virtue and morality. Second, it refers to the internal basis of the growth of all things. (Zhang, 1994:157). According to Chen Guying the relationship between "Tao" and "Te" are body and function, they are "two but one", and that Te is the function of Tao and the manifestation of Tao. In the process of creating life, Tao internalized in all things and become the attribute of all things, which is called Te. (Chen, 1999:12-13). In the process of interpreting Lao Tzu's Tao Te Ching, Fu Peirong often translates "Te" into natural endowment (referring to all things "get from Tao"). (Fu, 2010)

The translation strategies of “Te (德)" in the nine versions were different from those of "Tao". "Te" was used to be translated into Indonesian words (domestication) that means virtue in all of nine translation versions. For example: (Tan, 1937): boedi dharma, boedi kebedjikan; (Kwee 1938): kebadjikan, kebaekan, kebidjaksanaan; (Liem 1960): kebedjikan; (Tjan, 1962): kesaktian; (Majelis Tridharma, 1995): kebajikan, kebaikan; (Khrisna 1999): kebajikan, kebaikan, kesadaran; (Tjan 2007): kebajikan, moral, de; (Lika, 2012): budi pekerti, hati nurani, jasa, amal, de; (Wang, 2014): kebajikan, moral, de. The word Te (德) existed 44 times in 81 chapters of Tao Te Ching, while the transliteration of "De" pinyin only appeared eight times in Tjan 2007, Lika 2012 and Wang 2014 separately. It is clear that most of the nine translations adopted domestication strategy for the translation of "Te".

For example, the translation of chapter 21 Tao Te Ching, “孔德之容。惟道是从
Kong De zhi rong, wei dao shi cong" :

Tan 1937: Boedi Kebedjikan jang oeloeng poenja rasa dharma serta nerima anoet wet ketoehanan. (Te: virtue)

Kwee 1938: Kebedjikan yang paling besar bisa didapet tjoemah dengen meloeloe ikoetin Tao jang samar dan tida bisa didjadjakin. (Te: virtue)

Liem 1960: Kebadjikan jang dapat dikata terbesar, hanja jang sesuai dengan sifat Tao. (Te: virtue)

Tjan 1962: Wadjah kesaktian yang mewah adalah sesuai dengan "Djalan"jang diikuti. (Te: super power performance)

Majelis Tridharma 1995: Kebadjikan yang terbesar hanya yang sesuai dengan Tao. (Te: virtue)

Khrisna 1999: Kebajikan yang termulia adalah mengikuti Tao dan hanyalah Tao. (Te: virtue)

Tjan 2007: Orang yang sungguh bermoral tinggi, hanya dao-lah teladannya. (Te: have good morality)

Lika 2012: Hati Nurani dan Budi

Pekerti yang mulia hanya mengikuti Dao (Da Dao). (Te: conscience and virtue)

Wang 2014: Karakter orang yang tinggi kebajikannnya, selalu mengikuti jejak Dao. (Te: virtue)

In my opinion, the word “Te德” in the Tao Te Ching is more difficult to translate than the word "Tao道". Tao is the most important concept in the Tao Te Ching, its own meaning (meaning of existence, natural law, standard norms of life) can be understood as noun, and its meaning is selfsufficient. When it is transliterated into Dao or Tao, it feels more reasonable. The word "Te" in the Tao Te Ching existed on the ba- 
sis of "Tao". Its connotation is the function of Tao and its meaning is not self-sufficient. Therefore, the translation of "Te" is a little troublesome. When it is transliterated into $\mathrm{De} / \mathrm{Te}$, its meaning is even more unclear. When it is translated into Kebajikan (virtue), its complete meaning cannot be fully represented. For example, Chapter 51 of Tao Te Ching: “道生之, 德畜之Dao sheng zhi, De xu zhi". Translated by Fu Peirong: It comes from Tao/Dao and enriches by Te/De. He then explained “德畜 之De xu zhi": De is something that gets everything from Tao, referring to its nature or endowment, that is, to enrich its conditions of existence (Fu, 2015:99). Among the nine Indonesian versions, four versions (Tan 1937, Tjan 2007, Lika 2012, Wang 2014) adopted transliteration method for “De德” for this chapter translation, retaining the pronunciation of "De" (Teh (1937), and De (2007, 2012, 2014).

From the translations of the above Indonesian versions, it can be seen that the translators tried to understand every sentence in every chapter of the Tao Te Ching, and the treatment of the word "Te" was not exactly the same. This phenomenon is worthy of affirmation. Although the interpretation of the word "De德" in the translated version was generally confined to the meaning of virtue or morality, and does not fully reflect the complex meaning of "De 德” in the Tao Te Ching, but it still has an important contribution to convey the idea of "doing good things and accumulating morality" in the Tao Te Ching.

\section{Translation Strategies of "Ziran自然"}

"Ziran" in "Tao Te Ching" existed five times, all mean "oneself is like this" and "develops according to its inherent law". In the nine versions, "ziran was generally translated into Indonesian words, using domestication strategy. For example, the translation of Chapter 25 of the Tao Te Ching “道法自然Tao Fa Ziran” :

(Tan 1937): wet natuur menoelad permulaan dunia jang kekal (eternal beginning of the world)

(Kwee 1938): Tao poenja atoeran moentjoel dari dirinja sendiri (come out from itself)

(Liem 1960): Tao dari hukum sewadjarnja (usual law)

(Tjan 1962): Djalan berpedoman pada kodrat alam (nature law)

(Majelis Tridharma 1995): Tao dari hukum sewajarnya (usual law)

(Khrisna 1999): Tao itu sendiri mengikuti apa yang disebut alami (what is called natural)

(Tjan 2007): Dao meneladani dirinya sendiri (oneself)

(Lika 2012): Dao yang maha besar ya hanya mengikuti kehendaknya sendiri (oneself's will)

(Wang 2014): Dao mengikuti hukum alam (natural law)

From the "ziran" translations of this chapter, almost all the translations have the same understanding. Basically, it has been able to express "ziran" as an adjective to describe Tao's own state. No translation has ever understood "ziran" as the natural world or nature. It basically conforms to the meaning of Laozi's concept of natural philosophy (自然哲学ziran zhexue) in the Tao Te Ching.

Translation Strategies of "Wuwei 无为" The word "wuwei (无为)" in the Tao Te Ching refers to a state of mind in interper- 
sonal and personal relationships that conforms to nature, and does not focus on oneself only. The word "wuwei无为" existed 12 times in 81 chapters of Tao Te Ching. Among the nine versions, except the Wang 2014 version, “wuwei (无为)" was mostly translated into Indonesian words, with its meaning "no action or doing nothing", adopting domestication translation strategy. In Wang 2014 version, the translation adopted the strategy of foreignization, transliterating "wuwei无为" into “wuwei”, appearing 12 times, it means that all of the word "wuwei无为" in Tao Te Ching were transliterate into pinyin "wuwei". Other translations were rarely used transliteration strategies: Kwee 1938 (once), Liem 1960 (once), Majelis Tridharma 1995 (once), Lika 2012 (three times). For example, in Chapter 2 of the Tao Te Ching, “是以圣人 处无为之事, 行不言之教” (Shiyi Shengren Chu Wuwei Zhi shi, Xing Bu Yan Zhi Jiao) translated as follows:

Tan 1937: maka nabi agoeng mendoedoeki segala kerdjaan zonder memperboeat (without doing)

Kwee 1938: landataran begitoe orang Boediman tjoemah perhatiken sadja apa jang tidak mengandoeng sifat membentji. (no hate)

Liem 1960: dari itu seoran Nabi berada dalam kedudukan tidak berbuat (no action)

Tjan 1962: Inilah sebabnja orang sutji bekerdja tanpa bertindak (without doing)

Majelis Tridharma 1995: Maka dari itu orang suci berada dalam kedudukan tidak berbuat (not doing)

Khrisna 1999: Oleh karena itu, ia yang bijak melewati kehidupan ini tanpa bertindak (without doing)
Tjan 2007: Sebab itu, menghadapi apapun, orang suci selalu bersikap tanpa pamrih (not asking for return)

Lika 2012: oleh karena itu, Nabi/ Orang Suci selalu bersikap wuwei /无 为 (selalu berbuat baik tanpa pamrih) (wuwei, do good things not for return) Wang 2014: Hanya Seng Ren yang melakukan pekerjaan secara wuwei (wuwei)

In the nine versions of Indonesian translation, the translation of "wuwei无为" into "inaction or non-action" is actually only the superficial meaning of it. "wu无" means "nothing", and "wei为" means "doing". Therefore, the literal meaning of "wuwei无 为" is "not doing" or "doing nothing". This simple domestication translation cannot express the meaning of "wuwei无为". Foreignization strategy was adopted to solve this problem in Wang 2014 version, but foreignization translation could make the reader unable to understand its connotation. The Wang 2014 translation seemed to be aware of the reader's problem, so the translator explained some important philosophical terms in the Tao Te Ching before the translation texts. In this way, on the one hand, the original words of the important philosophical terms in the Tao Te Ching were retained, and on the other hand, the explanation of the meaning of this term was very helpful to the readers (Wang, 2012: $10)$.

\section{CONCLUSIONS}

As a traditional Chinese classic, Tao Te Ching was full of the particularity of Chinese traditional thoughts. When it is translated into foreign languages (including Indonesian), there is a dialogue between two 
cultures. Therefore, the translation of Tao Te Ching always exists in the tension between the two cultures (the original culture and the target culture). This tension also existed in the nine versions of Indonesian translations of the Tao Te Ching, as follows: (1) The pronunciation of the original (Chinese) title was preserved in the translation of the title of Tao Te Ching, and the interpretation of the target language (Indonesian) was added. This translation strategy is very good. On the one hand, it gives the reader the characteristics of the original culture. On the other hand, it helps the reader to summarize the main thought of the (original culture) book, so that the reader can see it at a glance. (2) The translation of the main philosophical terms (Dao, De, ziran and wuwei) in Tao Te Ching adopted different strategies. The translation strategies of "Tao" tend to be foreignized, while those of other terms tend to be domesticated. The translation strategies of philosophical terms in some translation texts were obviously extreme, for example: Tjan 1962 version adopted complete domestication strategy in the translation of the word Tao ( 道), translating all the Tao words exist in the whole text of Tao Te Ching into Indonesian word "Djalan" (The Way), while the Wang 2014 version translated the word wuwei (无为) existed in the whole book into "wuwei", retaining the phonetic characteristics of the original language. The tension between domestication and foreignization poles that existed in the nine versions of Indonesian translations of the Tao Te Ching has made the translations to be rich and colorful.

\section{REFERENCES}

Chen Guying陈鼓应 (1999). Lao Tzu Zhushi ji Pingjia 《老子注释及评 价》.Beijing北京: Zhonghua Shuju 中华书局。

Cui Yinghui崔莹辉 (2012). LaoTzu Yingyi Yanjiu 《老子英译研究. Shandong University Dissertation山东大学博士 学位论文。

Fu Peirong傅佩荣 (2015).Fu Peirong YijieLaoTzu《傅佩荣译解老 子》.Beijing北京: Dongfang Chubanshe东方出版社.

Liu Dianjue刘殿爵, Zhang Wanning章婉 凝 (2011). Dao Dejing English-Chinese Bilingual《道德经》英汉双 语.Beijing北京: Zhongyi Chubanshe中译出版社.

Kwee Tek Hoaij (1938). Tao Teh King. Tjitjoeroeg: Typ. Drukkerij "Moestika".

Krishna, A. (1999) Tao Teh Ching bagi Orang Modern. Jakarta: Penerbit Gramedia.

Liem Tjie Khay. (1960/1991). Tao Teh Ching. Surakarta: Penerbit Swastika, Djakarta: Bhratara.

Lika, I.D. (2012). Dao De Jing: Kitab Suci Utama Agama Tao. Jakarta: P.T. Elex Media Komputindo.

Majelis Rohaniwan Tridharma Seluruh Indonesia Komda Jakarta. (1995). Tao Tee Cing: Kitab Suci Taoisme.

Munday, J. (2014). Introducing Translation Studies: Theories and Applications (Chinese $3^{\text {rd }}$ ed). Beijing: Foreign Language and Research Press.

Budianto, P. (2016). A Preliminary Investigation of Indonesian Translations of the Tao Te Ching Texts for the 
sake of Chinese Language and Culture Education in Indonesia. Paper presented at The Third International Conference on Chinese Indonesian Studies (ICCIS): Contribution of Chinese Indonesian to Global Communities in the Past, Present and Future. In proceeding book published by Tarumanagara University Jakarta, p.31-36.

Tan Soe Djwan. (1937). Too Tik King: Kitab Kebatinan Lao Tse. Kediri: Boekhandel Tan Khoen Swie.

Tao Yuan \& Yu Fengjun. (2013). Foreignization of Tao Te Ching Translation in Western World, Journal of Language Teaching and Research, 4(3), 579-583. http://www.academypublication.com/issues/past/j1tr/ vo104/03/17.pdf. doi:10.4304/j1tr.4.3.579-583.
Tjan K. (2007). Dao De Jing: Kitab Kebijakan dan Kebajikan. Yogyakarta: Indonesiatera.

Tjan Tjoe Som. (1962). Tao-Te-Tjing. Jakarta: Bhratara.

Wang, A. (2014). DaoDeJing: The Wisdom of Lao Zi. Jakarta: P.T. Gramedia Pustaka Utama.

Yang Wenfeng (2010). Brief Study on Domestication and Foreignization in Translation. Journal of Language Teaching and Research, 1(1), 77-80. https: / / pdfs.semanticscholar. org / 4ca6/f4742f602595c3aedfc fd 4 a 06 f 7 feb 744 b 4 b.pdf . doi:10.4304/jltr.1.1.77-80

Zhang Dainian张岱年 (1999). Zhongguo Zhexue Gainian Fanchou Yaolun 《中 国哲学概念范畴要论. Beijing 北 京: Zhongguo Shehui Kexue Chubanshe中国社会科学出版社. 